\title{
Temporal Dynamics of Soybean Rust Associated With Leaf Area Index in Soybean Cultivars of different Maturity Groups
}

E. N. Moreira and F. X. R. Vale, Universidade Federal de Viçosa (UFV), Departamento de Fitopatologia, Viçosa, Minas Gerais State, Zip Code 36570-900, Brazil; P. A. Paul, The Ohio State University, Ohio Agricultural Research and Development Center, Wooster 44691; F. A. Rodrigues, UFV, Departamento de Fitopatologia, Viçosa, Minas Gerais State, Zip Code 36570-900, Brazil; and W. C. Jesus Júnior, Universidade Federal de São Carlos, Campus Lagoa do Sino, Buri, SP, CEP-18290-000, Brazil

\begin{abstract}
Moreira, E. N., Vale, F. X. R., Paul, P. A., Rodrigues, F. A., and Jesus Júnior, W. C. 2015. Temporal dynamics of soybean rust associated with leaf area index in soybean cultivars of different maturity groups. Plant Dis. 99:1216-1226.

Experiments were conducted in Mato Grosso, Brazil, from 2009 to 2011 to evaluate the effects of planting date (October, November, December, and January) on soybean rust (SBR) and leaf area index (LAI) in SBRsusceptible soybean cultivars of different maturity groups (earlymaturing, midseason, and late-maturing). Mean relative area under the LAI progress curve (RAULAIPC) was significantly higher $(P<0.05)$ for the late-maturing than early-maturing and midseason cultivars. The October planting date had significantly higher $(P<0.05)$ mean RAULAIPC than the December and January planting dates. Mean relative area under the SBR progress curve was significantly lower $(P<0.05)$ for the

late-maturing than the midseason and early-maturing cultivars, and significantly higher $(P<0.05)$ for the December and January than the October and November planting dates. Based on the logistic population growth model, SBR severity increased over time at a significantly higher mean rate for the early-maturing than the midseason and late-maturing cultivars. It took longer for SBR to reach a certain severity level for the late-maturing cultivar planted in January than the early-maturing cultivar planted in October. This implies that fungicides would need to be applied early to the early-maturing cultivar planted in October to minimize yield loss.
\end{abstract}

Since first being reported in South America in 2001, soybean rust (SBR), caused by Phakopsora pachyrhizi Syd., has caused significant losses in all major soybean (Glycine max (L.) Merr.) producing regions of Brazil (Yorinori and Morel 2002). SBR may occur at all stages of soybean growth (Bromfield and Yang 1976; Hsu and Wu 1968; Yang et al. 1990), and the level of damage caused varies depending on when infection occurs relative to the development of the crop. However, SBR most commonly develops between the flowering and pod-filling growth stages (Ogle et al. 1979; Sinclair and Hartman 1999). Under disease-favorable weather conditions, losses due to SBR were estimated at 10 to $40 \%$ in Thailand, 10 to $90 \%$ in India, 10 to $50 \%$ in China, 23 to $90 \%$ in Taiwan, and up to $40 \%$ in Japan (Hartman 1995). In Brazil, SBR-related losses as high as 70 to $100 \%$ were reported during the $2001 / 2002$ growing season (Yorinori and Morel 2002). In that season, Chapadão do Sul, in the state of Mato Grosso, was the region most severely affected, with losses of up to $100 \%$ (Andrade and Andrade 2002). However, the damage caused by SBR varies from one growing season to another, depending on the level of disease, which in turn is influenced by the characteristics of the cultivar planted (resistance, maturity, and yield potential) and the weather conditions under which the crop develops (Embrapa 2011).

Based on Embrapa's guidelines for crop production in Central Brazil, the recommended time for planting soybean is between mid-October and mid-December (Embrapa 2011). However, it is not uncommon for soybean to be planted outside of the recommended window. Planting date has been shown to affect growth and development of the crop, as well as the risk for pests and diseases. This is because weather conditions under which the crop develops, as well as the length of the growing season, may vary considerably from one planting date to another (Embrapa 2011). Among the main weather factors contributing to differences in productivity and disease levels

Corresponding author: P.A. Paul; E-mail: paul.661@osu.edu

Accepted for publication 25 November 2014.

http://dx.doi.org/10.1094/PDIS-10-14-1029-RE

(c) 2015 The American Phytopathological Society among planting dates are soil moisture and temperature during crop establishment, and particularly, the distribution of rainfall during reproductive growth stages. Depending on the cultivar, early planting in Central Brazil (before mid-October) usually ensures that adequate moisture is available during reproductive growth stages, but generally results in shorter, smaller plants (Embrapa 2011). Late-planted (after mid-December) soybean in Central Brazil usually has a shorter growth cycle and may be subjected to soil water deficit during the flowering and pod-filling stages of development. In addition, planting after mid-December usually results in plants being exposed to conditions favorable for pests and diseases, thus increasing the risk for losses caused by SBR and other diseases (Embrapa 2011).

Symptoms and signs of SBR are usually observed first on the lower leaves of the soybean plant, subsequently progressing up the canopy, eventually causing defoliation and reduction of the growth cycle of the crop (Embrapa 2011; Sinclair and Hartman 1999). Defoliation reduces leaf area and leaf area index (LAI), thus lowering light interception and net photosynthesis (Jesus Júnior et al. 2001a, b, 2003; Waggoner and Berger 1987). Jesus Júnior et al. (2003) indicated that yield loss is often associated with defoliation as well as reduction of the photosynthetic activity of the leaves (i.e., reduced effective leaf area index), based on research on angular leaf spot of common beans. In many cases, healthy and effective leaf area duration (HAD and ELAD) provide a better estimate of the effects of foliar diseases on their host than diseased leaf area (Bergamin Filho et al. 1997; Gaunt 1995; Jesus Júnior et al. 2003; Lopes and Berger 2001). However, HAD, ELAD, defoliation, and LAI may also affect the development and progress of SBR and other diseases caused by biotrophic pathogens. This is partly because biotrophs infect and develop on healthy, green leaf tissue (Bassanezi et al. 2001; Jesus Júnior et al. 2001a; Lopes and Berger 2001).

The effects of soybean plant growth on the temporal progress of SBR was previously investigated (Desborough 1984; Tschanz and Shanmugasundaram 1985; Tschanz and Tsai 1982), with results suggesting that the physiological age of the plant may play a significant role in disease progress. Tschanz and Tsai (1982) and Tschanz et al. (1986) showed a direct association between the maturity group of soybean cultivars and the rate of SBR progress. Based on studies conducted using three cultivars in two growing seasons, they observed that photoperiod also affected the progress of SBR. However, the association between SBR and development 
of the soybean plant is still very difficult to quantify because the functional relationship between the two is poorly understood (Yang et al. 1990).

Several approaches have been used to demonstrate and characterize the relationship between temporal disease progress and plant growth (Bergamin Filho et al. 1997, 2004; Gaunt 1995; Jeger 1983; Lalancette and Hickey 1986; Madden 1980; Waggoner and Berger 1987). For instance, Lalancette and Hickey (1986) derived composite population growth models to account for the change in disease intensity over time relative to the change in crop growth. They described their models as being either "similar-synchronous," "dissimilar-synchronous," "similar-nonsynchronous," and "dissimilar-nonsynchronous," in which similarity/dissimilarity refers to the form of the model describing the temporal change in disease intensity and crop growth, and synchrony/asynchrony to the coincidence of the two processes (disease development and crop growth). Madden et al. (2007) also discussed the importance of accounting for crop growth and development when fitting population growth models to disease progress data and provided several examples of how to incorporate in-season and season-to-season changes in crop density into such models.

Since the 2001/2002 SBR epidemic in Brazil, most of the research efforts have been directed toward evaluating fungicides and breeding for resistant to manage this disease. However, there are several unanswered questions pertaining to the epidemiology of SBR. For instance, it is unclear whether and how LAI, which is known to vary among growing seasons and soybean maturity groups, affects the progress of SBR under conditions favorable for epidemics. The overall goal of this study was to compare the progress of SBR among three soybean cultivars of different maturity groups, planted on four different dates. The specific objectives were to: i) model the temporal dynamics of LAI and SBR as influenced by cultivar maturity and planting date, ii) determine the effect of cultivar maturity and planting date on LAI and SBR, and iii) quantify the functional relationship between LAI and SBR as influenced by cultivar maturity and planting date. An understanding of these effects on the dynamics of SBR will be useful for risk assessment and management of this disease in the field.

\section{Materials and Methods}

Field plots and experimental design. Experiments were conducted at the Fundação de Apoio a Pesquisa e Desenvolvimento Integrado Rio Verde research station located in Lucas do Rio Verde, Mato Grosso, Brazil (latitude 12 ${ }^{\circ} 59^{\prime} \mathrm{S}$, longitude $55^{\circ} 57^{\prime} \mathrm{W}$, altitude $390 \mathrm{~m}$ ) during the 2009/2010 and 2010/2011 growing seasons. Three SBR susceptible soybean cultivars of determinate growth and different maturity groups (P98Y11RR, early-maturing [95 to 110 days]); MSOY-8527RR, midseason [111 to 120 days]); and MSOY-9144RR, late-maturing [above 121 days]) were planted in both seasons. These cultivars were likely between maturity groups 7 and 9 (Alliprandini et al. 2009), and representative of those grown in the state of Mato Grosso and recommended by Embrapa. Seeds were sown on 25 October, 19 November, and 14 December 2009 and on 8 January 2010 during the first season, and on 20 October, 19 November, and 15 December 2010 and 5 January 2011 during the second. Different planting dates were used to mimic standard soybean production practices in central Brazil (Embrapa 2011) and also to increase the likelihood of obtaining different SBR intensities at different crop growth stages. Hereafter, the first, second, third, and fourth planting dates will be referred to simply as October, November, December, and January planting dates, and the two growing seasons as the 2009 and 2010 seasons.

Plots were planted at the recommended seeding rates of 26, 24, and 22 seeds/ $\mathrm{m}^{2}$ for P98Y11RR, MSOY-8527RR, and MSOY-9144RR, respectively, and managed according to standard recommendations for soybean production in the state of Mato Grosso (Embrapa 2011). Specifically, seeds were treated with tiametoxana insecticide (Syngenta Proteção de Cultivos Ltda, São Paulo, SP) at a rate of $120 \mathrm{ml} /$ $100 \mathrm{~kg}$ of seed to control soil borne insects early in the season, and then with Bradyrizobium japonicum at a rate of $200 \mathrm{ml} / 100 \mathrm{~kg}$ of seed to enhance nitrogen fixation. For weed control, glyphosate (Monsanto do Brasil, Cuiaba, Mato Grosso, Brazil) was applied at a rate of 1.5 liters/ha at the V1 growth stage (Ritchie et al. 1982). The experimental design was a randomized complete block with a split-plot arrangement of planting date as whole-plot and cultivar as subplot. Each whole-plot was divided into three subplots, each consisted of $1220-\mathrm{m}$ long rows, spaced $0.50 \mathrm{~m}$ apart. There were four replicate blocks, giving a total of 48 plots (experimental units) in each experiment.

Data collection. Weather. Weather data were recorded with an automatic weather station (ISIS - Model S1220, Squitter Ambiental, São José dos Campos, São Paulo, Brazil) deployed at the site of each experiment when the soybean plants were at the V4 growth stage. Air temperature, relative humidity, rainfall, and leaf wetness duration were recorded at 15-min intervals. Leaf wetness was recorded using three sensors positioned at different heights within the canopy of the crop and adjusted periodically as the plants developed. The lowest (first) sensor was initially placed at the height of the first trifoliate, the uppermost sensor (third) at the top of the canopy, and the second approximately halfway between the first and the third.

SBR severity assessment. SBR severity was assessed at 7-day intervals between the V6 and R6 growth stages (Ritchie et al. 1982). Five plants were arbitrarily selected in each plot, and from each plant, all trifoliate leaves were removed and examined for the presence of SBR pustules with the aid of a stereoscopic microscope at $20 \times$ magnification. All leaves were examined within the first $48 \mathrm{~h}$ after they were collected. For each sample, the total number of leaflets and the number of leaflets with symptoms of SBR were recorded. SBR symptomatic leaflets were then scanned at a resolution of $300 \mathrm{dpi}$ and the images were analyzed using the image analysis software QUANT (Vale et al. 2003) to quantify the level of SBR. Severity was then estimated as the sum of all SBR symptomatic areas of all diseased leaflets in each sample (five plants), dividing by the total area of all leaflets, multiplied by 100 .

Area under the SBR progress curve. Disease severity scores were used to estimate the area under the SBR progress curve (AUSBRPC) as described by Shaner and Finney (1977). To adjust for differences in the duration of the epidemic among cultivars and planting dates, AUSBRPC was then divided by the length of the SBR assessment window (difference in days between the first and the last assessments) to obtain the relative area under the SBR progress curve (RAUSBRPC) as described by Fry (1978). RAUSBRPC was estimated as:

$$
R A U S B R P C=\frac{\sum_{i=1}^{n_{i}-1}\left(\frac{y_{i}+y_{i+1}}{2}\right) \cdot\left(t_{i+1}-t_{i}\right)}{d}
$$

where $y_{i}$ is the observed disease severity at the $i$-th assessment time $\left(t_{i}\right), n_{i}$ is the number of assessments, and $d$ is the duration of the assessment period (the total number of days between the first and last assessments).

Leaf area index (LAI) and leaf area duration (LAD). Leaf area assessments were made at 15-day intervals between the V3 to R6 growth stages or until complete plant defoliation. Two plants were arbitrarily collected from each plot, all trifoliate leaves were scanned, and the images were analyzed using QUANT to estimate the leaf area. LAI was then calculated as the total leaf area of the crop per unit ground area as previously described (Watson 1947). The LAI data were then used to estimate area under leaf area index progress curve (AULAIPC) using Equation 1, with $y_{i}$ representing the estimated LAI at each assessment time. To adjust for differences in the length of the growing season among cultivars and planting dates, relative AULAIPC (RAULAIPC) was estimated for each cultivar $\times$ planting date combination by dividing AULAIPC by the length of the growing season ( $d$ in Equation 1). LAD was calculated as the difference in days between the first LAI measurement (at V3) and the last (R6) or until complete defoliation.

Data analysis. SBR temporal dynamic modeling. Disease severity values were plotted over time for each experimental unit, and the nonlinear forms of the Logistic and Gompertz models (Madden et al. 2007) were fitted to the data for each growing season $\times$ cultivar $\times$ planting date $\times$ replicate combination using the NLIN procedure of SAS (Cary, NC). The models fitted to the data can be written as:

$$
y=\left(1+B e^{-r_{L} t}\right)^{-1}
$$

for the logistic model, and 


$$
y=\exp \left(-B e^{-r_{G} t}\right)
$$

for the Gompertz model, in which $B=\left(1-y_{0}\right) / y_{0}$ in Equation 2 and $-\ln \left(y_{0}\right)$ in Equation 3, $y=$ disease severity (as a proportion), $r_{L}$ and $r_{G}$ are rate parameters for the logistic and Gompertz models, respectively, $t=$ time, and $y_{0}=$ disease severity at the start of the epidemic (at V6, which was considered as $t=0$ ). Model fit was evaluated based on pseudo- $\mathrm{R}^{2}$ ( 1 - [residual sum of squares/corrected total sum of squares]), mean square error (MSE), and residual (difference between predicted and actual SBR severity) plots (Jesus Júnior et al. 2003; Madden et al. 2007). Models with relatively high pseudo- $\mathrm{R}^{2}$ values, low MSE, and a random scattering of the residuals were deemed as being appropriate for the data.

LAI/LAD relationship. To model relationships between $\mathrm{LAD}$ and LAI, nonlinear regression analysis was conducted using the NLIN procedure of SAS to fit a generalized beta function (Hau and Kranz 1990), with LAD as the predictor and LAI as the response. Data from the two experiments were pooled and separate models were fitted to the means for each cultivars $\times$ planting date combination. The model can be written as:

$$
y=B 1\left((X-B 2)^{B 4}\right) \cdot\left((B 3-X)^{B 5}\right)
$$

where $y=\mathrm{LAI}, B 2=$ minimum leaf area duration $\left(\mathrm{LAD}_{\min }\right), B 3=$ maximum leaf area duration $\left(\mathrm{LAD}_{\max }\right), X=\mathrm{LAD}$, and $B 1, B 4$, and $B 5$ are additional parameters estimated during model fitting.

Analysis of variance. Linear mixed models (Littell et al. 2006) were fitted to the data using Proc GLIMMIX of SAS (Cary, NC) to determine the effects of cultivar, planting date, and their interaction on RAUSBRPC, RAULAIPC, and the rate parameters $\left(r_{L}\right.$ and $r_{G}$ ) from the fit of population growth models to the SBR severity data. Separate analyses were performed for each response for each experiment, and the data were subsequently pooled and reanalyzed. In all cases, cultivar and planting date were fixed effects, and block, year (growing season), and all interactions involving block and year were random effects. The models fitted to the data can be written as:

$$
y_{i j l}=\theta+\alpha_{i}+\beta_{j}+(\alpha \beta)_{i j}+b_{l}+\alpha b_{i l}+e_{i j l}
$$

for each year, and

$$
y_{i j k l}=\theta+\alpha_{i}+\beta_{j}+(\alpha \beta)_{i j}+\varphi_{k}+b(\varphi)_{k l}+\alpha(b \varphi)_{i k l}+e_{i j k l}
$$

for the pooled data, where $y_{i j l}$ is the response (RAUSBRPC, RAULAIPC, $r_{L}$, and $r_{G}$ ) for the $i$-th planting date (PD) and $j$-th cultivar (CV) within the $l$-th block, $\theta$ is the constant (intercept), $\alpha_{i}$ is the effect of the $i$-th $\mathrm{PD}, \beta_{j}$ is the effect of the $j$-th $\mathrm{CV}, b_{l}$ is the effect of the $l$-th block, $(\alpha \beta)_{i j}$ is effect of the $i$-th PD $\times j$-th $\mathrm{CV}$ interaction, $\alpha b_{i l}$ is the effect of $i$-th PD $\times l$-th block interaction (the whole-plot error term), and $e_{i j l}$ is the residual. For the pooled data (model 5b), $y_{i j k l}$ is the response, $\varphi_{k}$ is the effect of the $k$-th year, $b(\varphi)_{k l}$ is the effect of the $l$-th block within the $k$-th year, and $\alpha(b \varphi)_{i k l}$ is the effect of the $i$-th PD within the $l$-th block within the $k$-th year. All other terms in $5 \mathrm{~b}$ are as described for 5 a. Fixed effects were evaluated with $F$ tests and random effects with standard normal test statistics.

Mixed model regression analysis. The analysis of the pooled data were subsequently expanded to model relationships between SBRrelated responses (RAUSBRPC, $r_{L}$, and $r_{G}$ ) and RAULAIPC as influenced by cultivar and planting date, through linear mixed model regression analysis (Littell et al. 2006). For these analyses, RAULAIPC was used as a continuous covariate, while cultivar and planted date were again treated as fixed effect factors. All random effects were as described in Equations 5a and 5b. The model fitted to the data, with random effects terms suppressed for ease of expression, was:

$$
y_{i j k l m}=\theta+\alpha_{i}+\beta_{j}+(\alpha \beta)_{i j}+\delta X_{m}+\Delta_{i} X_{m}+\gamma_{j} X_{m}+\vartheta_{i j} X_{m}+\ldots+e_{i j k l m}
$$

where $y_{i j k l m}$ is the response (RAUSBRPC, $r_{L}$, and $r_{G}$ ), $\theta, \alpha_{i}, \beta_{j}$, and $(\alpha \beta)_{i j}$ are as described above in Equation $5 \mathrm{a}, X_{m}$ is the $m$-th observation of the covariable RAULAIPC, $\delta$ is the effect of the covariable, $\Delta_{i}$ is the interaction effect of the covariable and PD, $\gamma_{j}$ is the interaction of the covariable and $\mathrm{CV}, \vartheta_{i j}$ is the interaction effect of the covariable, $\mathrm{PD}$, and $\mathrm{CV}$, and $e_{i j k l m}$ is the residual. Here, the $m$ subscript refers to each unique observation of the covariable. Models were first fitted with all of the terms, then nonsignificant terms $(P>0.05)$ were removed one by one, beginning with the interactions. Regression parameters were compared among cultivars and planting dates using the lsmeans and estimate statement in GLIMMIX.

\section{Results}

Field conditions and crop development. Weather conditions (temperature, relative humidity, and rainfall) during the two years (2009 and 2010) were favorable both for the development of soybean plants as well as to the progress of SBR. During the first year, temperatures ranged from 22 to $30^{\circ} \mathrm{C}$, with an average of $26^{\circ} \mathrm{C}$ (Fig. 1A). Average nighttime relative humidity (RH) ranged from 65 to $99.8 \%$, with an average of $90 \%$ (Fig. 1C), and cumulative rainfall was $1,465 \mathrm{~mm}$ (Fig. 1C). Similar conditions were recorded in 2010, with temperatures ranging from 22 to $29^{\circ} \mathrm{C}$, with an average of $27^{\circ} \mathrm{C}$ (Fig. 1B), and nighttime RH from 56 to $100 \%$, with an average of $89 \%$ (Fig. 1D). Cumulative rainfall was $1,604.5 \mathrm{~mm}$ (Fig. 1D). Mean temperatures were fairly similar, but mean nighttime RH and total rainfall varied among planting dates within each year. Averaged between planting and harvest, mean temperature was approximately $26^{\circ} \mathrm{C}$ for all four planting dates in 2009 , and between 25 and $26^{\circ} \mathrm{C}$ in 2010 . Nighttime RH was slightly higher during the first year, with means of $86,88,87$, and $85 \%$ for the October, November, December, and January planting dates, respectively. The corresponding means for the second year were 82,84 , 87 , and $87 \%$. During the first growing season, total rainfall was highest for the October planting date $(1,236 \mathrm{~mm})$, followed by the November (896 mm), December $(902 \mathrm{~mm})$, and January $(575 \mathrm{~mm})$ planting dates. During the 2010 growing season, total rainfall was higher for the first $(537 \mathrm{~mm})$ and third $(546 \mathrm{~mm})$ planting dates than for the second $(438 \mathrm{~mm})$ and fourth $(317 \mathrm{~mm})$.

For both years, the length of the growth cycle varied among planting dates and among cultivars within each planting date (Fig. 2). For each cultivar, the growth cycle got progressively shorter as planting was delayed, resulting in the earliest and latest planting dates having the longest and shortest cycles, respectively. As expected, in all cases, the early-maturing cultivar had the shortest growth cycle (78 to 106 days, depending on the planting date), followed by the midseason (91 to 112 days), and late-maturing (97 to 127 days) cultivars. The difference in length of the growth cycle between the earlyand late-maturing cultivars was between 14 to 20 days.

Leaf area index and leaf area duration. For all cultivars and planting dates, in both experiments, similar trends were observed in terms of the temporal change in LAI. In all cases, LAI increased over time, reaching a maximum between 62 and 82 days after V3, then decreased rapidly thereafter (Fig. 3). Depending on the cultivar and planting date, maximum LAI ranged from 2.3 to 4 ; it occurred earlier for the early-maturing cultivar, followed by the midseason and late-maturing cultivars, and was lowest for the early-maturing cultivar and highest for the late-maturing cultivar for all four planting dates. For all cultivars, the maximum LAI became progressively lower as planting was delayed, resulting in the October and January planting dates having the highest and lowest LAI peaks, respectively (Fig. 3).

Averaged across experiments, mean maximum leaf area duration $\left(L A D_{\max }\right)$ varied with cultivar and planting date (inserts in Figure 3). For the October planting date, the $\mathrm{LAD}_{\max }$ values were 104,111 , and 125 for the early-maturing, midseason, and late-maturing cultivars, respectively. The corresponding values were 98,111 , and 118 for the November planting date; 86, 98, and 106 for the December planting date; and 81,92 , and 98 for the January planting date. Based on results from the nonlinear regression analyses, the generalized beta model was appropriate for modeling the relationship between LAI and LAD. All model parameters were statistically significant $(P<0.05)$, and the $\mathrm{R}^{2}$ values (for relationship between predicted and actual LAI) of the early-maturing, midseason, and late-maturing cultivars were 0.84 , 0.82 , and 0.89 for the first planting date; $0.88,0.82$, and 0.84 for second 
planting date; $0.94,0.94$, and 0.78 for the third planting date; and 0.78 , 0.92, and 0.82 for the fourth planting date (Fig. 3).

In both experiments, for all planting dates, the RAULAIPC was highest for the late-maturing cultivar and lowest for the earlymaturing cultivar, and for all cultivars, mean RAULAIPC decreased as planting was delayed, resulting in October and January having the highest and lowest means in all cases (Fig. 4). Results from linear mixed model analyses of the effects of cultivar and planting date on RAULAIPC showed that the main effects of cultivar and planting date, but not their interaction, were statistically significant in the first year. In the second season, both the main and interaction effects of cultivar and planting dates were statistically significant (Table 1). All pairwise differences in mean RAULAIPC between cultivars were statistically significant for all planting dates in both seasons, but the magnitude of the differences tended to be greater for the October and November planting dates $(0.40$ to 0.94$)$ than for the December and January planting dates $(0.20$ to 0.65$)$ in the second season (hence the significant interaction) (Fig. 4B). In general, mean RAULAIPC was significantly different between all pairs of planting dates, except for pairwise comparisons among the last three planting dates (November, December, and January) for the early-maturing cultivar in both seasons and comparisons between the December and January planting dates for the midseason cultivar in both seasons and the late-maturing cultivar in the first season (Table 2).

Soybean rust development. Since SBR severity was assessed at 7-day intervals between the V6 and R6 growth stages, V6 was considered as time zero. For all cultivars, the epidemic began and ended progressively later as planting was delayed (Fig. 5). The first measurable level of disease was recorded a week after time zero for the first planting date (October). For the second planting (November), disease onset was 21 days after time zero for the early-maturing cultivar and 27 days after time zero for the midseason and late-maturing cultivars, whereas for the December and January planting dates, the first symptoms of SBR were observed 34 and 41 days after time zero, respectively, on all three cultivars. Depending on the planting date, final SBR severity ranged from 75 to $96 \%$ (mean $87 \%$ ), 57 to $85 \%$ (mean $73 \%$ ), and 48 to $78 \%$ (mean $63 \%$ ) for the early-maturing, midseason, and later-maturing cultivars, respectively.

Both the logistic and Gompertz population growth models were appropriate for describing the temporal change in SBR intensity, with similar pseudo- $\mathrm{R}^{2}$ values, mean square error (MSE), and patterns of residual plots (data not shown). Therefore, to avoid redundancy, only parameter estimates from the fit of the logistic model are presented and discussed hereafter. For the logistic model, pseudo- $\mathrm{R}^{2}$ values
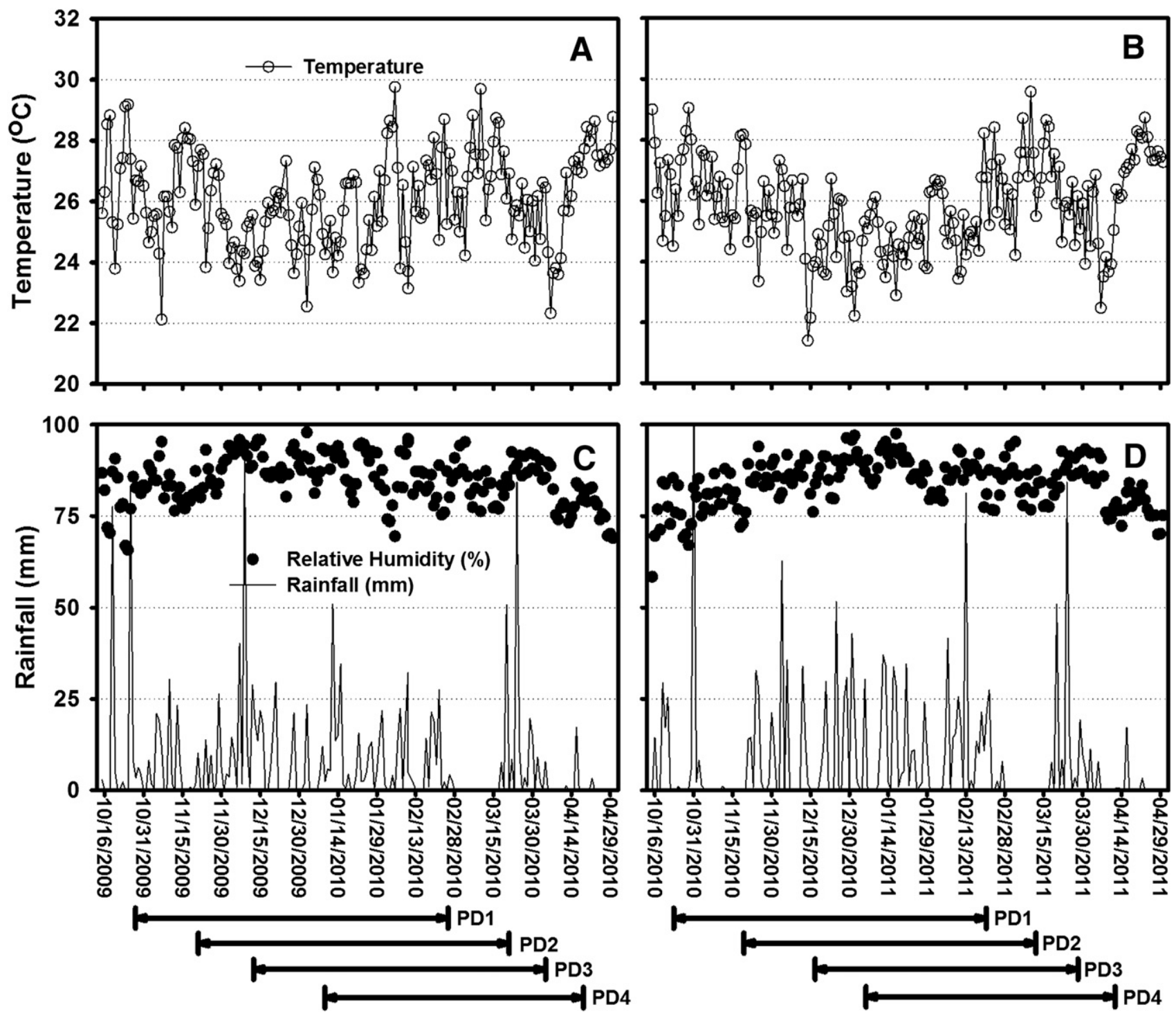

Fig. 1. Mean daily temperature $\left({ }^{\circ} \mathbf{C}\right)(\mathbf{A}$ and $\mathbf{B})$, total rainfall ( $\mathbf{C}$ and $\mathbf{D}$, solid lines) and average nighttime relative humidity ( $\mathbf{C}$ and $\mathbf{D}$, black dots) for the period between 15 October 2009 and 30 April 2010 during the 2009/2010 (A and C) and 2010/2011 (B and D) growing seasons in Lucas do Rio Verde, Mato Grosso, Brazil. Vertical bars below the x-axes indicate the length of the growing seasons for each of four planting dates (PD1, PD2, PD3, and PD4). 
ranged 0.97 to 0.99 and MSE from $4 \times 10^{-5}$ to $2.2 \times 10^{-3}$. The logistic rate parameters $\left(r_{L}\right)$ ranged from 0.05 to 0.14 (severity as a proportion per day). Averaged across years, mean $r_{L}$ ranged from 0.10 to

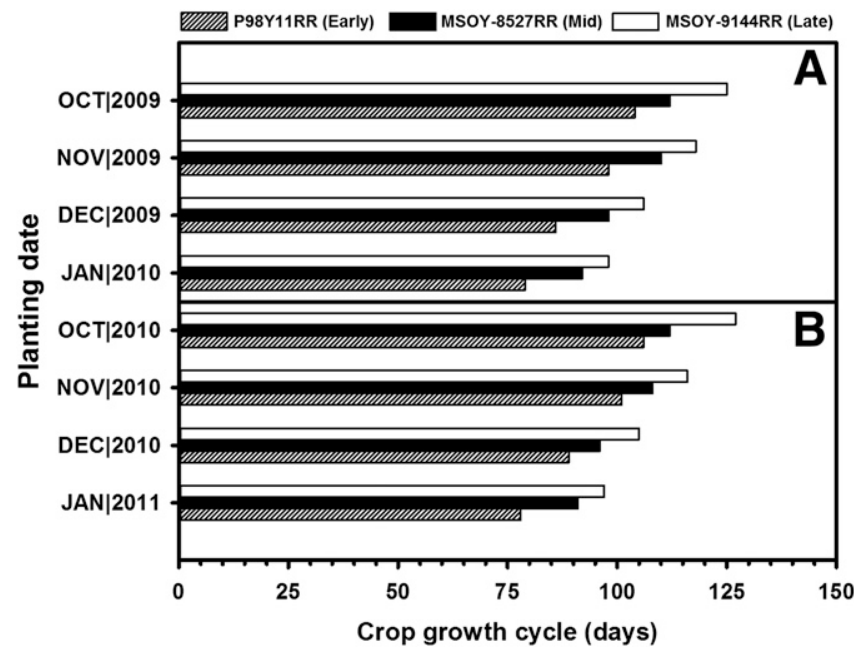

Fig. 2. Length of the growing season (days) for three SBR-susceptible soybean cultivars of different maturity-P98Y11RR, early-maturing (Early); MSOY-8527RR, midseason (Mid); and MSOY-9144RR, late-maturing (Late)-planted on four dates (October, November, December, and January) during the 2009/2010 (A) and 2010/ 2011 (B) growing seasons in Lucas do Rio Verde, Mato Grosso, Brazil.
0.13 for the early-maturing cultivar, compared with 0.06 to 0.09 for the midseason cultivar and 0.06 to 0.08 for the late-maturing cultivar (Fig. 5). Solving the logistic model equations in Figure 5 for time (inverse regression [Madden et al. 2007]), we estimated the number of days it took from V6 for SBR to reach $50 \%$ of the maximum (final) severity for each cultivar $\times$ planting date combination. Depending on the planting date, the estimated time to reach $50 \%$ final severity was 9 and 16 days longer for the late-maturing cultivar than the early maturing cultivar, 2 to 12 days longer for the midseason cultivar than the early-maturing cultivar, and 4 to 10 days longer for the late-maturing cultivar than the midseason cultivar.

The RAUSBRPC tended to increase as planting was delayed and was generally highest for the early-maturing and lowest for the latematuring cultivar in both experiments (Fig. 4). Results from the linear mixed model analysis showed that in both years, the main effects of cultivar and planting date on RAUSBRPC were statistically significant $(P<0.005)$, but their interaction was not (Table 1). Averaged across planting dates, mean RAUSBRPC was significantly lower for the late-maturing cultivar than for the early-maturing and midseason cultivars (Table 3 ). However, the difference between the earlymaturing and midseason cultivars varied from one season to the next, being statistically significant in the second, but not the first. Among the planting dates, averaged across cultivars, mean RAUSBRPC was higher for the December and January planting dates than for the October and November planting dates in both seasons, with the differences being statistically significant $(P<0.05)$ in most cases (in 8 of 9 comparisons) and marginally significant $(P<0.06)$ for comparison between the December and November planting dates in the second

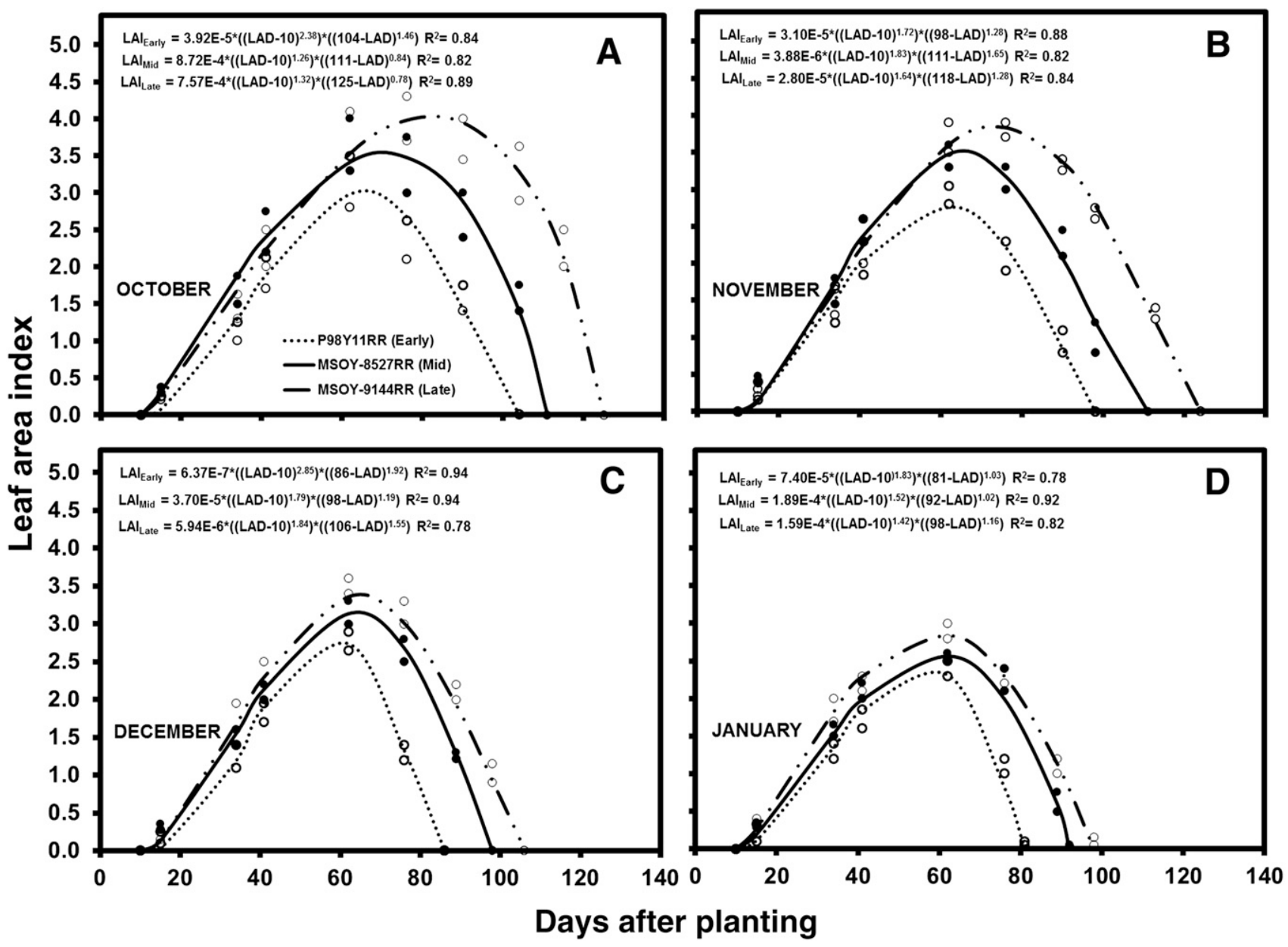

Fig. 3. Leaf area index (LAl) for three SBR-susceptible soybean cultivars of different maturity—P98Y11RR, early-maturing (Early, dotted line); MSOY-8527RR, midseason (Mid, solid line); and MSOY-9144RR, late-maturing (Late, broken line and dots) - planted on four dates (October [A], November [B], December [C], and January [D]) during the 2009/2010 and 2010/2011 growing seasons in Lucas do Rio Verde, Mato Grosso, Brazil. Lines represent predicted LAl for the relationship between leaf area duration (LAD) and LAl from nonlinear regression fit of a generalized beta function (Equation 4) to the pooled data. Model equations are inserted in each graph. Each dot represents mean LAI averaged across the four blocks from each experiment. 
season (Table 3). The difference in mean RAUSBRPC between the last two planting dates was not statistically significant.

When cultivar and planting date were evaluated for their effects on the temporal rate of change in SBR severity $\left(r_{L}\right)$, somewhat similar trends to those observed for RAUSBRPC were evident. Note that
$r_{L}$ represents the increase in diseased leaf area per unit diseased leaf area per unit healthy leaf area per unit time; however, for simplicity, we refer to it here as the percent increase in SBR severity per day. As discussed by Madden et al. (2007), since diseased leaf area cancels out and healthy leaf area is represented as a proportion in the model,
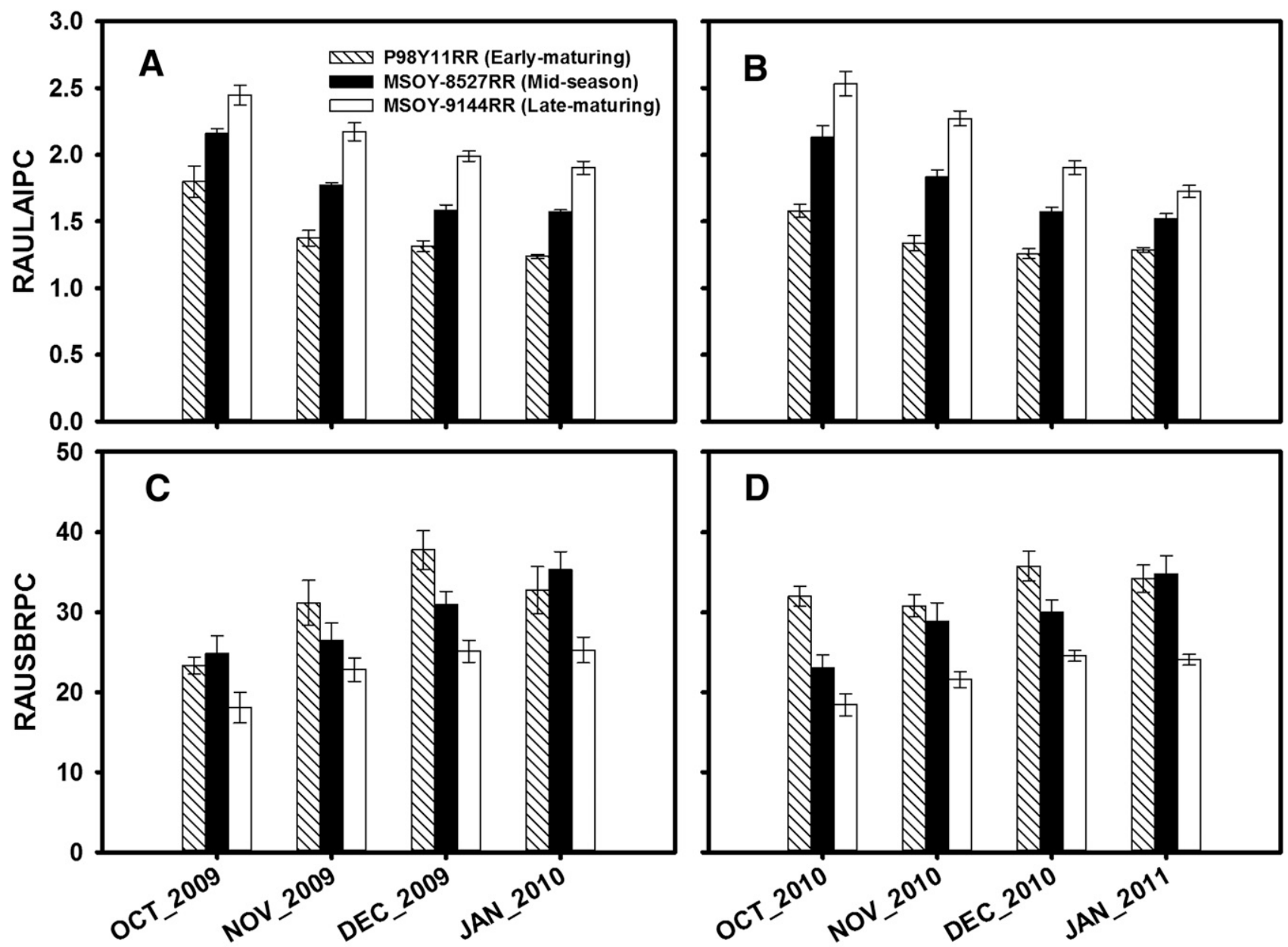

Planting Date

Fig. 4. Mean relative area under the leaf area index progress curve (RAULAIPC, $A$ and $B$ ) and mean relative area under the soybean rust progress curve (RAUSBRPC, $C$ and $D$ ) for three SBR-susceptible soybean cultivars (P98Y11RR, early-maturing; MSOY-8527RR, midseason; and MSOY-9144RR, late-maturing) planted on four dates (October, November, December, and January) during the 2009/2010 (A and C) and 2010/2011 (B and D) growing seasons in Lucas do Rio Verde, Mato Grosso, Brazil. Each bar represents the arithmetic mean of four replicates and the error bars are standard errors of the means.

Table 1. Summary statistics from linear mixed model analyses of the effects of planting date (PD) and soybean cultivar (CV) on relative area under soybean leaf area index progress curve (RAULAIPC), relative area under soybean rust (SBR) progress curve (RAUSBRPC), and logistic SBR temporal progress rate parameter $\left(r_{L}\right)$ for field experiments conducted in Lucas do Rio Verde, Mato Grosso, Brazil

\begin{tabular}{|c|c|c|c|c|c|c|c|}
\hline \multirow[b]{2}{*}{ Response } & \multirow[b]{2}{*}{ Factor $^{\mathbf{a}}$} & \multicolumn{2}{|c|}{ Experiment $1^{b}$} & \multicolumn{2}{|c|}{ Experiment $2^{b}$} & \multicolumn{2}{|c|}{ Pooled ${ }^{b}$} \\
\hline & & $F$ value & $P$ & $F$ value & $P$ & $F$ value & $P$ \\
\hline \multirow{3}{*}{ RAULAIPC } & $\mathrm{PD}$ & 83.88 & $<0.001$ & 160.19 & $<0.001$ & 193.40 & $<0.001$ \\
\hline & $\mathrm{CV}$ & 169.89 & $<0.001$ & 722.04 & $<0.001$ & 447.06 & $<0.001$ \\
\hline & $\mathrm{PD}^{*} \mathrm{CV}$ & 0.64 & 0.700 & 20.48 & $<0.001$ & 4.75 & $<0.001$ \\
\hline \multirow[t]{3}{*}{ RAUSBRPC } & PD & 21.16 & $<0.001$ & 9.10 & 0.004 & 27.68 & $<0.001$ \\
\hline & $\mathrm{CV}$ & 15.94 & $<0.001$ & 57.06 & $<0.001$ & 53.93 & $<0.001$ \\
\hline & $\mathrm{PD}^{*} \mathrm{CV}$ & 1.27 & 0.309 & 2.18 & 0.081 & 1.68 & 0.143 \\
\hline \multirow[t]{3}{*}{$r_{L}$} & PD & 42.71 & $<0.001$ & 31.08 & $<0.001$ & 69.95 & $<0.001$ \\
\hline & CV & 113.93 & $<0.001$ & 136.93 & $<0.001$ & 245.56 & $<0.001$ \\
\hline & $\mathrm{PD}^{*} \mathrm{CV}$ & 3.59 & 0.011 & 3.70 & 0.010 & 5.81 & $<0.001$ \\
\hline
\end{tabular}

${ }^{a} \mathrm{PD}=$ planting date - plots were planted on 25 October, 19 November, and 14 December 2009 and 8 January 2010 in Experiment 1, and on 20 October, 19 November, and 15 December 2010 and 5 January 2011 in Experiment 2. CV = SBR-susceptible soybean cultivars of different maturity: P98Y11RR, earlymaturing (95 to 110 days); MSOY-8527RR, midseason (111 to 120 days); and MSOY-9144RR, late-maturing (above 121 days).

b Experiments 1 and 2 were conducted during the 2009/2010 and 2010/2011 growing seasons, respectively. Pooled refers to the combined analysis of data from the two experiments. $F$ statistic and $P$ value (significance level) from the linear mixed model analyses. 
Table 2. Probability values ( $P$, level of significance) for pairwise comparisons of least square means between planting dates (PD) for different cultivars $(C V)$ from linear mixed model analysis of CV and PD effects on relative area under soybean leaf area index progress curve (RAULAIPC) for field experiments conducted in Lucas do Rio Verde, Mato Grosso, Brazil

\begin{tabular}{|c|c|c|c|c|}
\hline \multirow[b]{2}{*}{ Cultivar ${ }^{\mathrm{a}}$} & \multirow[b]{2}{*}{ Comparison $^{\mathbf{b}}$} & \multicolumn{3}{|c|}{ RAULAIPC } \\
\hline & & Experiment 1 & Experiment 2 & Pooled $^{\mathrm{c}}$ \\
\hline \multirow{6}{*}{ Early-maturing } & PD 1 versus PD 2 & $<0.001$ & $<0.001$ & $<0.001$ \\
\hline & PD 1 versus PD 3 & $<0.001$ & $<0.001$ & $<0.001$ \\
\hline & PD 1 versus PD 4 & $<0.001$ & $<0.001$ & $<0.001$ \\
\hline & PD 2 versus PD 3 & 0.418 & 0.074 & 0.141 \\
\hline & PD 2 versus PD 4 & 0.069 & 0.255 & 0.050 \\
\hline & PD 3 versus PD 4 & 0.297 & 0.492 & 0.616 \\
\hline \multirow[t]{6}{*}{ Midseason } & PD 1 versus PD 2 & $<0.001$ & $<0.001$ & $<0.001$ \\
\hline & PD 1 versus PD 3 & $<0.001$ & $<0.001$ & $<0.001$ \\
\hline & PD 1 versus PD 4 & $<0.001$ & $<0.001$ & $<0.001$ \\
\hline & PD 2 versus PD 3 & 0.014 & $<0.001$ & $<0.001$ \\
\hline & PD 2 versus PD 4 & 0.009 & $<0.001$ & $<0.001$ \\
\hline & PD 3 versus PD 4 & 0.865 & 0.255 & 0.509 \\
\hline \multirow[t]{6}{*}{ Late-maturing } & PD 1 versus PD 2 & $<0.001$ & $<0.001$ & $<0.001$ \\
\hline & PD 1 versus PD 3 & $<0.001$ & $<0.001$ & $<0.001$ \\
\hline & PD 1 versus PD 4 & $<0.001$ & $<0.001$ & $<0.001$ \\
\hline & PD 2 versus PD 3 & 0.018 & $<0.001$ & $<0.001$ \\
\hline & PD 2 versus PD 4 & $<0.001$ & $<0.001$ & $<0.001$ \\
\hline & PD 3 versus PD 4 & 0.240 & $<0.001$ & 0.006 \\
\hline
\end{tabular}

a SBR-susceptible soybean cultivars of different maturity: P98Y11RR, early-maturing (95 to 110 days); MSOY-8527RR, midseason (111 to 120 days); and MSOY-9144RR, late-maturing (above 121 days).

b Planting date $=$ plots were planted in October (PD 1), November (PD 2), December (PD 3), and January (PD 4) in field experiments conducted during the 2009/ 2010 (Experiment 1) and 2010/2011 (Experiment 2) growing seasons.

c Pooled refers to the combined analysis of data from the two experiments.

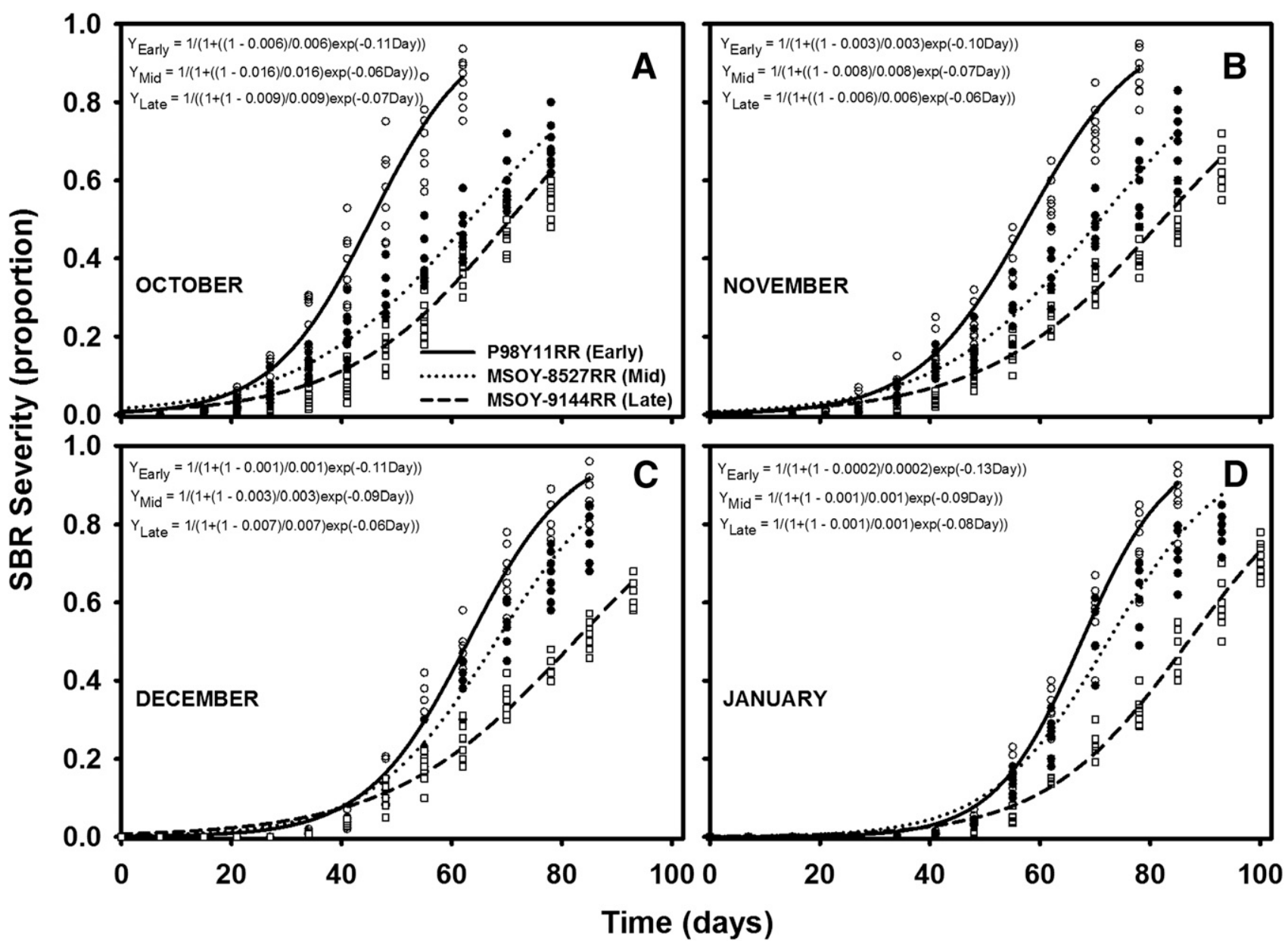

Fig. 5. Soybean rust (SBR) progress curves for three SBR-susceptible soybean cultivars of different maturity—P98Y11RR, early-maturing (Early, solid line and open circle); MSOY8527RR, midseason (Mid, dotted line and closed circle); and MSOY-9144RR, late-maturing (Late, broken line and open square)-planted on four dates (October [A], November [B], December [C], and January [D]) during the 2009/2010 and 2010/2011 growing seasons in Lucas do Rio Verde, Mato Grosso, Brazil. Lines represent predicted SBR severity as a proportion from nonlinear regression fit of the logistic population growth model. Model equations are inserted in each graph. Each dot represents the mean SBR severity for each block from each experiment. 
$r_{L}$ has units of time ${ }^{-1}$. In both seasons, the main and interaction effect of cultivar and planting date on mean $r_{L}$ were statistically significant (Table 1). SBR severity increased over time at a significantly higher mean rate for the early-maturing cultivar than the midseason and latematuring cultivars in both seasons (Table 4). All pairwise differences in mean $r_{L}$ between cultivars were statistically significant, except for comparisons between the midseason and late-maturing cultivars for the first and second planting dates (Table 4). For the late-maturing cultivar, the mean rate of SBR progress was fairly constant among planting dates, with only the January planting date having significantly higher $r_{L}$ than the November and December planting dates in both years. By contrast, for the midseason cultivar, all pairwise comparisons between planting dates, except between the first two and between the last two dates, were statistically significant in both years, with SBR tending to progress faster for later than earlier planting dates. For the early-maturing cultivar, the effect of planting date on $r_{L}$ tended to be much more variable between the first and second years (data not shown). For instance, the January planting date had significantly higher mean $r_{L}$ than the October and November planting dates in both years, but the significance of the difference for other pairs of planting date comparisons varied from one year to the next.

Effect of LAI on SBR development. Results from linear mixed model regression analyses of the relationship between RAUSBRPC and RAULAIPC as influenced by cultivar and planting date showed that there was a significant negative functional relationship between the two variables (Fig. 6A). None of the interactions involving the covariate (RAULAIPC) were statistically significant, suggesting that the rate of reduction in RAUSBRPC per unit increase in RAULAIPC was not influenced by cultivar, planting date, or their interaction. Therefore, a model for the relationships can be written as RAUSBRPC $=a_{i}+b$ (RAULAIPC), where $a_{i}=$ intercept for each cultivar (or planting date) and $b=$ common slope (rate of change in RAUSBRPC per unit increase in RAULAIPC). RAUSBRPC decreased at a rate of $11.5(\mathrm{se}=1.66)$ per unit increase in RAULAIPC (Fig. 6A). The height of the regression line (RAUSBRPC at a fixed RAULAIPC) was greatest for the midseason cultivar, followed by the early-maturing and the late-maturing cultivars, but only the difference in height of the line between midseason and the latematuring cultivars was statistically significant $(P=0.028)$.

The rate of SBR increase over time $\left(r_{L}\right)$ also decreased as RAULAIPC increased (Fig. 6B), with cultivar and planting date (but not their interaction) having a significant $(P<0.001)$ effect on the slope of the regression line (i.e., the cultivar $\times$ RAULAIPC and planting date $\times$ RAULAIPC

Table 3. Probability values ( $P$, level of significance) for pairwise comparisons of least square means between cultivars (CV) and between planting dates (PD) from linear mixed model analyses of CV and PD effects on relative area under soybean rust progress curve (RAUSBRPC) for field experiments conducted in Lucas do Rio Verde, Mato Grosso, Brazil

\begin{tabular}{llrcr}
\hline & & \multicolumn{3}{c}{ RAUSBRPC } \\
\cline { 3 - 5 } Factor $^{\mathbf{a}}$ & Comparison & Experiment 1 & Experiment 2 & Pooled $^{\mathbf{b}}$ \\
\hline Cultivar & Early versus mid & 0.246 & $<0.001$ & 0.003 \\
& Early versus late & $<0.001$ & $<0.001$ & $<0.001$ \\
& Mid versus late & $<0.001$ & $<0.001$ & $<0.001$ \\
Planting date & PD 1 versus PD 2 & 0.006 & 0.095 & 0.001 \\
& PD 1 versus PD 3 & $<0.001$ & 0.003 & $<0.001$ \\
& PD 1 versus PD 4 & $<0.001$ & 0.001 & $<0.001$ \\
& PD 2 versus PD 3 & 0.009 & 0.059 & 0.001 \\
& PD 2 versus PD 4 & 0.011 & 0.020 & $<0.001$ \\
& PD 3 versus PD 4 & 0.902 & 0.530 & 0.701 \\
\hline
\end{tabular}

a Cultivar = SBR-susceptible soybean cultivars of different maturity: P98Y11RR, early-maturing (Early); MSOY-8527RR, midseason (Mid); and MSOY9144RR, late-maturing (Late). Planting date $=$ plots were planted in October (PD 1), November (PD 2), December (PD 3), and January (PD 4) in field experiments conducted during the 2009/2010 (Experiment 1) and 2010/2011 (Experiment 2) growing seasons.

${ }^{b}$ Pooled refers to the combined analysis of the data from the two experiments.
Table 4. Probability values ( $P$, level of significance) for pairwise comparisons of least square means between cultivars (CV) at different planting dates (PD) from linear mixed model analysis of $\mathrm{CV}$ and $\mathrm{PD}$ effects on logistic soybean rust progress rate parameter $\left(r_{L}\right)$ for field experiments conducted in Lucas do Rio Verde, Mato Grosso, Brazil

\begin{tabular}{llrrr}
\hline & & \multicolumn{3}{c}{$\boldsymbol{r}_{\boldsymbol{L}}$} \\
\cline { 3 - 5 } Planting date $^{\mathbf{a}}$ & Comparison $^{\mathbf{b}}$ & Experiment 1 & Experiment $2^{2}$ & Pooled $^{\mathbf{c}}$ \\
\hline PD 1 & Early versus mid & $<0.001$ & $<0.001$ & $<0.001$ \\
& Early versus late & $<0.001$ & $<0.001$ & $<0.001$ \\
& Mid versus late & 0.387 & 0.990 & 0.530 \\
PD 2 & Early versus mid & $<0.001$ & $<0.001$ & $<0.001$ \\
& Early versus late & $<0.001$ & $<0.001$ & $<0.001$ \\
& Mid versus late & 0.835 & 0.073 & 0.138 \\
PD 3 & Early versus mid & $<0.001$ & $<0.001$ & $<0.001$ \\
& Early versus late & $<0.001$ & $<0.001$ & $<0.001$ \\
& Mid versus late & $<0.001$ & 0.009 & $<0.001$ \\
PD 4 & Early versus mid & $<0.001$ & $<0.001$ & $<0.001$ \\
& Early versus late & $<0.001$ & $<0.001$ & $<0.001$ \\
& Mid versus late & 0.012 & 0.003 & $<0.001$
\end{tabular}

a Planting date $=$ plots were planted in October $($ PD 1), November (PD 2), and December 2009 (PD 3), and January (PD 4) in field experiments conducted during the 2009/2010 (Experiment 1) and 2010/2011 (Experiment 2) growing seasons.

b Comparisons between pairs of SBR-susceptible soybean cultivars of different maturity: P98Y11RR, early-maturing (Early); MSOY-8527RR, midseason (Mid); and MSOY-9144RR, late-maturing (Late).

c Pooled refers to the combined analysis of the data from the two experiments.
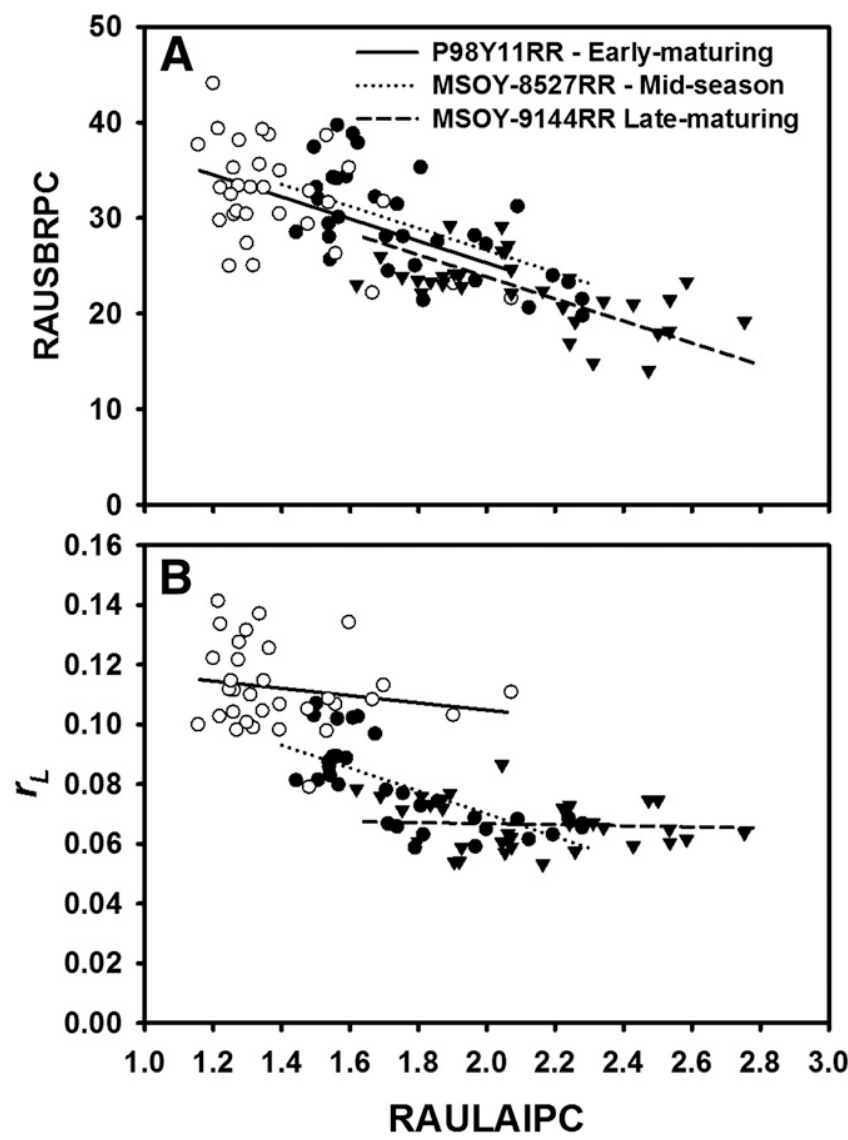

Fig. 6. Relationships between relative area under the soybean rust (SBR) progress curve (RAUSBRPC) and relative area under the leaf area index progress curve (RAULAIPC) (A) and between SBR logistic rate parameter $\left(r_{L}\right)$ and RAULAIPC $(B)$ for three SBRsusceptible soybean cultivars of different maturity-P98Y11RR, early-maturing (solid line and open circle); MSOY-8527RR, midseason (dotted line and closed circle); and MSOY-913RR, late-maturing (broken line and closed triangle)-planted in field experiments conducted during the 2009/2010 and 2010/2011 growing seasons in Lucas do Rio Verde, Mato Grosso, Brazil. Lines represent predicted responses from linear mixed model regression analysis of the pooled data. Each dot represents the mean RAUSBRPC and mean $r_{L}$ for each block from each experiment. 
interactions were statistically significant). A generic model for this relationship can be written as $r_{L}=a_{i}+b_{i}$ (RAULAIPC), where $a_{i}$ are $b_{i}$ are separate intercepts and slopes, respectively, for each cultivar (or planting date). The rate of $r_{L}$ reduction per unit increase in RAULAIPC $\left(b_{i}\right)$ was $-0.012,-0.038$, and -0.002 for the early-maturing, midseason, and late-maturing cultivars, respectively. The slope was significantly greater (higher negative value) for the midseason cultivar than the early- and late-maturing cultivars, but the difference between the latter two cultivars was not statistically significant $(P=0.317)$. Among the planting dates, the rate on reduction in SBR progress per unit increase in RAULAIPC was significantly greater for the December and January planting dates than the October and November dates, with slopes of -0.07 and -0.08 for December and January and -0.05 and -0.04 for October and November.

\section{Discussion}

During the 2 years of this study, weather conditions were highly favorable the development of both SBR and soybean. Temperature, relative humidity, and rainfall were within the range of values favorable for natural $P$. pachyrhizi infection (Del Ponte et al. 2006; Marchetti et al. 1976; Melching et al. 1089; Sinclair and Hartman 1999; Yang et al. 1990), leading to high levels of disease in both years. This allowed us to successfully model the temporal progress of SBR as influenced by cultivar maturity, planting date, and LAI. Models were also developed for the relationship between LAI and LAD. Both the logistic and Gompertz population growth models appropriately described the temporal progress of SBR, and the generalized beta function was adequate for describing the relationship between LAD and LAI. In both years, cultivar (maturity) and planting date had a significant effect on area under the LAI and SBR progress curves and the logistic rate parameter $\left(r_{L}\right)$. There were significant negative linear relationships between RAULAIPC and RAUSBRPC and between RAULAIPC and $r_{L}$, with cultivar and planting date having a significant effect on the slope of the $r_{L}$ /RAULAIPC regression line but not the RAUSBRPC/ RAULAIPC line.

Mean RAULAIPC decreased as planting was delayed, resulting in the October and January planting dates having the highest and lowest mean RAULAIPC, respectively, for all cultivars. This is consistent with results from other studies, and has been reported to occur even when foliar disease levels are low (Hu 2013). The length of the growing season is one of several factors that affects LAI, and based on the fact that RAULAIPC was highest for the planting date with the longest growing seasons, one may assume that this factor was likely responsible for the observed response. However, RAULAIPC is a standardized response, which allowed us to compare planting dates after adjusting for the length of the growing season. This suggests that the length of the growing season was likely not the only (or even the primary) factor affecting LAI in this study. Other factor that could explain our results are photoperiod, solar radiation, and temperature (Yang et al. 1990; Young et al. 2012). Different planting dates likely resulted in plants being exposed to different photoperiods, with those planted in October and November (the latter half of the spring in the Mato Grosso region of Brazil) being exposed to longer photoperiods during their development than those planted in December and January (midsummer in Mato Grosso). This likely resulted in higher total leaf area and LAI for the former two planting dates than the latter two. Investigating the effects of solar radiation on SBR and LAI (among other factors), Young et al. (2012) also observed that early-planted (11 April 2008 and 24 April 2009) soybean had significantly higher LAI than late planted soybean (4 August 2008 and 23 July 2009) under field conditions in Florida. They also reported that early-planted experimental units that received 32 to $55 \%$ less solar radiation had significantly lower LAI than those that received 65 to $100 \%$ radiation, relative to full sunlight. Based on their findings, they hypothesized that longer day lengths (photoperiod) in early planted soybean caused solar radiation to have a greater effect on plant physiology, leading to greater differences in LAI and SBR among treatments.

Coupled with environmental conditions, SBR also likely affected LAI, leading to differences among planting dates. For all three cultivars, RAULAIPC was considerably higher for the October and
November planting dates than the December and January planting dates. The latter two planting dates had the highest levels of SBR, based on mean RAUSBRPC, and in most cases, the greatest temporal rates of SBR progress. In addition to reducing the healthy leaf area of the soybean plant, SBR also causes defoliation (Kumudini et al. 2008; Miles et al. 2007; Mueller et al. 2009; Yang et al. 1990), which reduces leaf area (Fehr et al. 1981), and consequently, light interception, LAD, and, LAI (Board et al. 2010; Waggoner and Berger 1987). Studying the effect of planting date and cultivar on soybean rust in Taiwan, Yang et al. (1990) found a significant positive straightline relationship between soybean defoliation and SBR severity, with between 63 and $81 \%$ of the variation in defoliation explained by variation in SBR severity. For every percent increase in SBR severity, there was between a 0.58 and $0.76 \%$ increase in defoliation, depending on the cultivar and planting date. Mueller et al. (2009) and Miles et al. (2007) also reported a significant positive correlation between defoliation and SBR (as area under the SBR progress curve) for experiments conducted in Paraguay, Zimbabwe and the United States.

Our findings provide evidence of the effect of LAI (or plant growth in general) on the development and temporal dynamics of SBR. The cultivar with the highest RAULAIPC (and $\mathrm{LAD}_{\max }$ ) tended to have the lowest RAUSBRPC and, in most cases, the lowest temporal rates of SBR progress $\left(r_{L}\right)$. This was consistent across growing seasons and planting dates. Our models for relationships between RAUSBRPC and RAULAIPC and $r_{L}$ and RAULAIPC showed that both RAUSBRPC and $r_{L}$ decreased as RAULAIPC increased. This inverse association between LAI and SBR could be attributed to several factors, including defoliation, a process that removed diseased leaf tissue from the system, and differences between the plant and the disease in terms of relative growth or increase. Under the conditions of this study, plants likely developed at a faster rate than the rate at which SBR developed, thus "diluting" disease severity on the whole-plant scale, and consequently, the plot scale. The LAI and SBR progress curves support this hypothesis, showing that for all cultivar $\times$ planting date combinations, LAI peaked before SBR severity. So even though SBR showed a positive increase over time for all three cultivars, more extended growth for the late-maturing than the early-maturing cultivar likely caused mean whole-plant and plotlevel SBR severity to be lower in the former than the latter cultivar. Tschanz and Wang (1987), Yorinori and Morel (2002), and Hartman (1995) also observed strong associations between soybean maturity groups and SBR development. According to Yorinori and Morel (2002), the emergence of new trifoliate leaves on soybean plants during the early stages of SBR development may reduce disease severity (on a relative scale). Similar results were obtained by Diaz et al. (2005).

Differences in the development of SBR among cultivars and planting dates could also be attributed to differences in weather conditions (Twizeyimana et al. 2011; Yang et al. 1990) and complex interactions among weather, cultivar growth habit and maturity, and components of crop development such as LAI and LAD. For instance, SBR tends to develop best under moderate temperatures, high relative humidity, and prolonged cloud cover (Del Ponte and Esker 2008), and usually begins in the lower canopy where conditions are cooler and solar radiation is generally lower than in the upper canopy. Therefore, one would have expected higher levels of disease and higher rates of progress in cultivars or growing seasons with denser canopies (high LAI). However, the inverse relationship between RAULAIPC and RAUSBRPC observed in this study suggests that canopy micro climate was likely not the primary driver of differences among cultivars and planting date in terms of SBR development. The growth cycles overlapped considerably among cultivars for a given planting date and among planting dates in a given year, resulting in plants of all cultivars being exposed to similar ambient conditions in all planting dates. In other studies in which the effects of cultivar maturity (and growth habit) and planting date on SBR were investigated, planting dates were spaced more widely than in our study. This led to plants developing under different weather conditions, which was ultimately responsible for differences in SBR development among 
cultivars and planting dates (Twizeyimana et al. 2011; Yang et al. 1990).

Here we successfully determined the effects of cultivar maturity and planting date on LAI and SBR, quantified the effects of LAI on SBR severity (based on AUDPC) and the rate of SBR progress, and modeled the temporal dynamics of SBR and LAI. Our results provide further insight into the development of SBR as influenced by cultivar, planting date, and LAI, and will serve as the basis for future studies to develop more complex models to account for the effects of growth of the soybean plant on the temporal dynamics of SBR (Lalancette and Hickey 1986; Madden et al. 2007). Findings from this study could also be useful for making SBR management decisions. We demonstrated that parameters from the population growth models could be used to estimate the time it takes for SBR to reach a certain level of severity for each cultivar $\times$ planting date combination. This information could potentially be used in combination with SBR prediction and yield loss models to help guide fungicide application decisions. For instance, if 30\% SBR severity is the critical level of disease at which yield loss is likely to occur (and consequently fungicide application would be warranted), our models show, through inverse prediction, that it would take approximately 23 days longer for severity to reach this threshold on the earlymaturing susceptible cultivar when planted in January than October. Comparing cultivars at the early planting date, it would take 20 days longer for SBR severity to reach the $30 \%$ threshold on the latematuring cultivar than on the early-maturing cultivar. This information suggests that fungicides (a rate-reducing management strategy) need to be applied earlier on the early-maturing than the latematuring cultivar, and earlier for the October than the January planting date in order to minimize yield loss due to SBR. It also provides an estimate of the length of the fungicide decision window for each cultivar $\times$ planting date combination.

\section{Acknowledgments}

This research was supported by grants from Conselho Nacional de Desenvolvimento Científico e Tecnológico - CNPq (Process 201478/2011 and 303623/2010-1). Salary and research support for P.A. Paul were provided by state and federal funds to the Ohio Agricultural Research and Development Center (OARDC). Special thanks to the department of plant pathology at Ohio State University for hosting the first author between spring and fall 2012 .

\section{Literature Cited}

Alliprandini, L. F., Abatti, C., Bertagnolli, P. F., Cavassim, J. E., Gabe, H. L., Kurek, A., Matsumoto, M. N., de Oliveira, M. A. R., Pitol, C., Prado, L. C., and Steckling, C. 2009. Understanding soybean maturity groups in Brazil: environment, cultivar classification, and stability. Crop Sci. 49: 801-808.

Andrade, P. J. M., and Andrade, D. F. A. 2002. Ferrugem Asiática: uma ameaça à sojicultura brasileira. EMBRAPA Agropecuária Oeste Convênio Fundação Chapadão - Circular Técnica n. 11. M. S. Dourados, ed.

Bassanezi, R. B., Amorim, L., Bergamin Filho, A., Hau, B., and Berger, R. D. 2001. Accounting for photosynthetic efficiency of bean leaves with rust, angular leaf spot and anthracnose to assess crop damage. Plant Pathol. 50: 443-452.

Bergamin Filho, A., Carneiro, S. M. T. P. G., Godoy, C. V., Amorim, L., Berger, R., and Hau, B. 1997. Angular leaf spot of Phaseolus bean: relationships between disease, healthy leaf area, and yield. Phytopathology 87:506-515.

Bergamin Filho, A., Hau, B., Amorim, L., and Jesus Júnior, W. C. 2004. Análise espacial de epidemias. Pages 195-236 in: Epidemiologia aplicada. 1st Ed. F. X. R. Vale, W. C. Jesus Júnior, and L. Zambolim, eds. Editora Perffil, Belo Horizonte, Brazil

Board, J. E., Kumudini, S., Omielan, J., Prior, E., and Kahlon, C. S. 2010. Yield response of soybean to partial and total defoliation during the seed-filling period. Crop Sci. 50:703-712.

Bromfield, K. R., and Yang, C. Y. 1976. Soybean rust: Summary of available knowledge. Pages 161-164 in: Expanding the Use of Soybeans. R. M. Goodman, ed. INTSOY Series No. 10. Univ. of Illinois, Urbana-Champaign.

Del Ponte, E. M., and Esker, P. D. 2008. Meteorological factors and Asian soybean rust epidemics - a systems approach and implications for risk assessment. Scientia Agricola 65:88-97.

Del Ponte, E. M., Godoy, C. V., Li, X., and Yang, X. B. 2006. Predicting severity of Soybean rust epidemics with empirical rainfall models. Phytopathology 96 : 797-803.

Desborough, P. J. 1984. Selection of cultivar and sowing date as a strategy for avoidance of rust (Phakopsora pachyrhizi Syd.) losses in coastal New South Wales. Aust. J. Exp. Agric. Anim. Husb. 24:433-439.
Díaz, C. G., Ploper, L. D., Galvez, M. R., Gonzalvez, V., Zamorano, M. A., Jaldo, H. E., Lopez, C., and Ramallo, J. C. 2005. Effect of late season diseases on the growth of different soybean genotypes in relation to planting date. Agriscientia $21: 1-7$

EMBRAPA. 2011. Tecnologias de Produção de Soja - Região Central do Brasil 2012 e 2013. Sistemas de Produção 15. Centro Nacional de Pesquisa de Soja, Londrina.

Fehr, W. R., Lawrence, B. K., and Thompson, T. A. 1981. Critical stages of development for defoliation of soybean. Crop Sci. 21:259-262.

Fry, W. E. 1978. Quantification of general resistance of potato cultivars and fungicide effects for integrated control of potato late blight. Phytopathology 68:1650-1655.

Gaunt, R. E. 1995. The relationship between plant disease severity and yield Annu. Rev. Phytopathol. 33:119-144.

Hartman, G. L. 1995. Highlights of soybean rust research at the Asian Vegetable Research and Development Center. Pages 19-28 in: Proceedings of the Soybean Rust Workshop, 9-11 Aug. 1995. J. B. Sinclair, ed. College of Agricultural, Consumer, and Environmental Sciences, National Soybean Research Laboratory, Urbana, IL.

Hau, B., and Kranz, J. 1990. Mathematics and Statistics for Analyses in Epidemiology. Pages 12-52. in: Epidemics of Plant Disease: Mathematics Analysis and Modeling. J. Kranz, ed. Springer-Verlag, Berlin.

Hsu, C. M., and Wu, L. C. 1968. Study on soybean rust. Sci. Agric. 16: $186-188$.

Hu, M. 2013. Effects of Late Planting Dates, Maturity Groups and Management Systems on Growth, Development and Yield of Soybean in South Carolina. M.S. thesis, Plant and Environmental Sciences, Clemson University, Clemson, SC.

Jeger, M. J. 1983. Asymptotes of disease: equilibria between host growth and lesion increase? In: Proc. Int. Workshop Curr. Status of Bot. Epidemiol. North Carolina State University, Raleigh, NC.

Jesus Junior, W. C., Vale, F. X. R., Coelho, R. R., Hau, B., Zambolim, L., Costa, L. C., and Bergamim Filho, A. 2001. Effects of angular leaf spot and rust on yield loss of Phaseolus vulgaris. Phytopathology 91:1045-1053.

Jesus Junior, W. C., Vale, F. X. R., Coelho, R. R., Paul, P. A., Hau, B., Bergamin Filho, A., Zambolim, L., and Berger, R. 2003. Relationships among angular leaf spot, healthy leaf area, effective leaf area and yield of Phaseolus vulgaris. Eur. J. Plant Pathol. 109:625-63.

Jesus Junior, W. C., Vale, F. X. R., Martinez, C. A., Coelho, R. R., Costa, L. C., Hau, B., and Zambolim, L. 2001. Effects of angular leaf spot and rust on leaf gas exchange and yield of common bean (Phaseolus vulgaris). Photosynthetica 39:603-606.

Kumudini, S., Godoy, C. V., Board, J. E., Omielan, J., and Tollenaar, M. 2008. Mechanisms involved in soybean rust-induced yield reduction. Crop Sci. 48 : 2343-2350.

Lalancette, N., and Hickey, K. D. 1986. Disease progression as a function of plant growth. Phytopathology 76:1171-1175.

Littell, R. C., Milliken, G. A., Stroup, W. W., Wolfinger, R. D., and Schabenberger, O. 2006. SAS for Mixed Models, 2nd Ed. SAS Institute Inc., Cary, NC.

Lopes, D. B., and Berger, R. D. 2001. The effects of rust and anthracnose on the photosynthetic competence of diseased bean leaves. Phytopathology 91: 212-220.

Madden, L. V. 1980. Quantification of disease progression. Prot. Ecol. 2:159-176.

Madden, L. V., Hughes, G., and Van Den Bosch, F. 2007. The Study of Plant Disease Epidemics. The American Phytopathological Society, APS Press, St. Paul, MN.

Marchetti, M. A., Melching, J. S., and Bromfield, K. R. 1976. The effects of temperature and dew period on germination and infection by uredospores of Phakopsora pachyrhizi. Phytopathology 66:461-463.

Melching, J. S., Dowler, W. M., Koogle, D. L., and Royer, M. H. 1989. Effects of duration, frequency, and temperature of leaf wetness periods on soybean rust. Plant Dis. 73:117-122.

Miles, M. R., Levy, C., Morel, W., Mueller, T., Steinlage, T., van Rij, N., Frederick, R. D., and Hartman, G. L. 2007. International fungicide efficacy trials for the management of soybean rust. Plant Dis. 91:1450-1458.

Mueller, T. A., Miles, M. R., Morel, W., Marois, J. J., Wright, D. L., Kemerait, R. C., Levy, C., and Hartman, G. L. 2009. Effect of fungicide and timing of application on soybean rust severity and yield. Plant Dis. 93:243-248.

Ogle, H. J., Byth, D. E., and Mclean, R. J. 1979. Effect of rust (Phakopsora pachyrhizi) on soybean yield and quality in South-eastern Queensland. Aust. J. Agric. Res. 30:883-893.

Ritchie, S., Hanway, J. J., and Thompson, H. E. 1982. How a soybean plants develops. Spec. Rep. 53. Iowa State University of Science and Technology, Cooperative Extension Service, Ames, IA.

Shaner, G., and Finney, R. E. 1977. The effect of nitrogen fertilization on the expression of slow-mildewing resistance in Knox wheat. Phytopathology 67: $1051-1056$

Sinclair, J. B., and Hartman, G. L. 1999. Soybean Rust. Pages 3-4. in: Compendium of Soybean Diseases, 4th Ed., G. L. Hartman, J. B Sinclair, and J. C. Rupe, eds. The American Phytopathological Society, St. Paul. 
Teng, P. S. 1985. A comparison of simulation approaches to epidemic modelling. Annu. Rev. Phytopathol. 23:351-379.

Tschanz, A. T., and Shanmugasundaram, S. 1985. Soybean Rust. Pages 562-567 in: Proceedings of the 3rd World Soybean Research Conference. R. Shibles, ed. Ames, Iowa.

Tschanz, A. T., and Tsai, B. Y. 1982. Effect of maturity on soybean rust development. Soybean Rust Newsl. 5:38-41.

Tschanz, A. T., and Wang, T. C. 1987. Interrelationship between soybean development, resistance and Phakopsora pachyrhizi. Soybean Rust Newsl. 8:14-18.

Tschanz, A. T., Wang, T. C., and Tai, B. Y. 1986. Recent advances in soybean rust research. Pages 237-247. in: Soybean in Tropical and Subtropical Cropping Systems. S. Shanmugasundaram, ed. Asian Vegetable Research and Development Center, Shanhua, Taiwan.

Twizeyimana, M., Ojiambo, P. S., Hartman, G. L., and Bandyopadhyay, R. 2011. Dynamics of soybean rust epidemics in sequential plantings of soybean cultivars in Nigeria. Plant Dis. 95:43-50.
Vale, F. X. R., Fernandes Filho, E. I. F., and Liberato, J. R. 2003. QUANT - A software for plant disease severity assessment. In: International Congress of Plant Pathology, 8. Christchurch, New Zealand.

Waggoner, P. E., and Berger, R. D. 1987. Defoliation, disease and growth Phytopathology 77:393-398.

Watson, D. J. 1947. Comparative physiological studies in the growth of field crops. I. Variation in net assimilation rate and leaf area between species and varieties, and within and between years. Ann. Bot. (Lond.) 11:41-76.

Yang, X. B., Royer, M. H., Tschanz, A. T., and Tsia, B. Y. 1990. Analysis and quantification of soybean rust epidemics from seventy-three sequential planting experiments. Phytopathology 80:1421-1427.

Yorinori, J. T., and Morel, W. P. 2002. Ferrugem da soja (Phakopsora pachyhrizi): Alerta: Embrapa. Centro Nacional de Pesquisa de Soja, Londrina, Brazil.

Young, H. M., George, S., Narváez, D. F., Srivastava, P., Schuerger, A. C., Wright, D. L., and Marois, J. J. 2012. Effect of solar radiation on severity of soybean rust. Phytopathology 102:794-803. 